\title{
Bredemeyera floribunda Wild Elemental Content and Comparison with Nutritional Recommendation for Adults: Medicinal Plant Used by the Brazilian Rural Population to Treat Fatigue and Exhaustion
}

\author{
Paula Fabiana Saldanha Tschinkel1, Elaine Silva de Pádua Melo', Daniela Granja Arakaki', \\ Valdir Aragão do Nascimento ${ }^{1}$, Melina Ribeiro Fernandes', Nayara Vieira Lima1, \\ Luana Carolina Santos Leite ${ }^{1}$, Hugo Santos Pereira' ${ }^{2}$, Kassia Roberta Nogueira da Silva ${ }^{2}$, \\ Francisco José Mendes dos Reis ${ }^{1}$, Valter Aragão do Nascimento ${ }^{{ }^{*}}$
}

\begin{abstract}
${ }^{1}$ Group of Spectroscopy and Bioinformatics Applied to Biodiversity and Health, School of Medicine, Postgraduation Program in Health and Development in the Midwest Region, Federal University of Mato Grosso do Sul, School of Medicine, Campo Grande, Brazil

${ }^{2}$ Institute of Chemistry of the Federal University of Mato Grosso do Sul, Campo Grande, Brazil

Email: *aragao60@hotmail.com
\end{abstract}

How to cite this paper: Tschinkel, P.F.S., Melo, E.S.P., Arakaki, D.G., do Nascimento, V.A., Fernandes, M.R., Lima, N.V., Leite, L.C.S., Pereira, H.S., da Silva, K.R.N., dos Reis, F.J.M. and do Nascimento, V.A. (2020) Bredemeyera floribunda Wild Elemental Content and Comparison with Nutritional Recommendation for Adults: Medicinal Plant Used by the Brazilian Rural Population to Treat Fatigue and Exhaustion. American Journal of Plant Sciences, 11, 323-343. https://doi.org/10.4236/ajps.2020.113024

Received: February 9, 2020

Accepted: March 10, 2020

Published: March 13, 2020

Copyright $\odot 2020$ by author(s) and Scientific Research Publishing Inc. This work is licensed under the Creative Commons Attribution International License (CC BY 4.0).

http://creativecommons.org/licenses/by/4.0/

\section{(c) (i) Open Access}

\begin{abstract}
Bredemeyera floribunda Wild (Polygalaceae), also known as pau-de-ovo is a medicinal plant used to treat snakebites, as tonic and fortifiers to treat fatigue and exhaustion. The aim of the present study was to document the knowledge of herbal sellers in the preparation of the so-called " $B$. floribunda fortifier" and to compare the plant root content with the recommended nutritional values and the permitted limit for medicinal plants. The study revealed that, unlike other regions of Brazil, in the Midwest region, the root of the plant is used as food to treat fatigue and exhaustion. The contents in B. floribunda root decreased in the following order: $\mathrm{Ca}>\mathrm{K}>\mathrm{P}>\mathrm{Na}>\mathrm{Fe}>\mathrm{Mg}>\mathrm{Si}>$ $\mathrm{Mn}>\mathrm{Zn}>\mathrm{Cu}$. Daily intake of 30 grams of $B$. floribunda roots are considered as an excellent source of $\mathrm{Cr}, \mathrm{Cu}, \mathrm{Mn}$ and Se for people 19 to 50 years of age according to the RDA. In addition, $\mathrm{Cu}$ and Fe showed content above the established limit for medicinal plants stipulated by other countries. The root of the plant has low $\mathrm{K}, \mathrm{Mg}, \mathrm{P}, \mathrm{Na}$ and $\mathrm{Zn}$ content. When the contents in roots of the plant are below the oral dose of reference, consumption of this plant can be considered safe and without risk to human health. On the other hand, concentration of elements such as $\mathrm{Cu}, \mathrm{Fe}, \mathrm{Ni}, \mathrm{Al}, \mathrm{Cr}$ and Se exceeding the allowable limit may cause serious health problems due to prolonged ingestion
\end{abstract}


and large amounts consumed daily. The Brazilian legislation does not establish a permissible limit of macro- and micro-elements in medicinal plants; thus, the results presented in this study will contribute to the Brazilian public health policy on medicinal plants.

\section{Keywords}

Macroelements, Microelements, Bredemeyera floribunda Wild, Pau-De-Ovo, ICP OES

\section{Introduction}

The use of traditional medicine and the remedies employed on it has been encouraged by World Health Organization, since their secular use could confirm their efficacy as medicine [1]. In recent years, traditional medicine has drawn attention from both scientists and general population for various reasons, such as the high price of allopathic medicine and the side effects that they could lead, the lack of access to medical clinics and hospitals by the rural population, as well as the realization of the effectiveness of traditional medicine and its treatments [2]. Moreover, the medicinal plants represent over than $50 \%$ of all drugs in clinical use in the world [3].

Brazil is considered to be the rich country in terms to plant diversity known to science [4]. Bredemeyera floribunda Wild is a Polygalaceae, popular known as raiz-de-cobra (Portuguese for snakeroot) e pau-de-ovo (Portuguse, Brazil) [5]. Nowadays, the most popular use to B. floribunda is still against snake venom [6], but rural population also uses it to treat amoebic dysentery, rheumatism and as diuretic [7], and as a tonic [5], its use is indicated against dermatitis and insect bites [8]. The fortifying effect is also much sought after by rural population, who uses shaved roots added to water to provide energy and boost immunity.

The effects to treat snake venom of $B$. floribunda have been supported by the findings of Pereira et al. (1996) that isolated a saponin (Bredemeyroside D) with this effect [9]. The use as diuretic and as hypotensive agent was proved by Bevevino et al. (1994), who linked these results to the presence of triterpenoid saponins [7].

Some macronutrients and micronutrients are nutritionally essential elements, while some heavy metals are relatively harmful. Potassium [10], magnesium [11], iron [12], calcium [13], phosphorous [14], sodium [15], zinc [16] and selenium [17] are important for human health, however, high intake or lack of these elements can be dangerous [10]-[17]. Ingestion of foods with high levels of elements such as chromium, copper and manganese can cause neurological disorders and liver disease [18]. Nickel intake comes from nickel in drinking water, food and polluted environments, which causes a variety of pathological effects [19]. Another element absorbed by humans due to food intake is aluminum, according to studies; the presence of this metal in the body causes neu- 
ro-degenerative diseases especially Alzheimer's, autoimmune diseases and even breast cancer [20].

Several authors around the world have reported in many studies the quantification of heavy or essential metals in medicinal or edible plants [21]-[26]. However, only a few studies have investigated whether medicinal plants have sufficient contents to meet health requirements [22] [26] [27].

Data on macroelements and microelements present in the B. floribunda roots were quantified by ICP OES [28]; however, to date, the nutritional role or toxicity potential of this plant have not been elucidated according safety standards for the consumption of human beings. In addition, we have not found studies in the literature on how to prepare plant root fortifier. Therefore, documentation of medicinal plants used for the treatment and management of human disease by some rural and indigenous communities is important for public health [29]. In fact, the permissible limits of macroelements and microelements for medicinal plants have not yet been set by Brazil and others countries. Although many studies have been conducted towards knowing $B$. floribunda molecular structure, none has described its mineral content, nor linked its medicinal uses to it. The knowledge on elemental composition of $B$. floribunda is very important, once these plant is used to treat ailments and as a fortifier. It is important to avoid possible intoxications in acute or chronic consumption due to ingestion of medicinal plants.

The main objective of this study was 1) to report the method of preparation of the so-called " $B$. floribunda fortifier" and its dosage, 2) to compare the contents of $B$. floribunda roots detected in [28] with tolerable maximum intake levels established by Dietary Reference Intakes (RDI) for males, females and lactating aged 19 - 50 years [30], and 3) to compare the values with those recommended by World Health Organization (WHO) and other countries for medicinal plants.

Macro- and micronutrients requirements vary depending on age and sex [30], as well as, level of physical activity, dietary habits and pregnancy are also important factors [31]. According to studies, breastfeeding women have higher nutritional needs due to their increased physiological body needs to breastfeed the baby [32]. Hence, to the best of our knowledge, this researches is the first to describe the nutritional role of $B$. floribunda roots, and the preparation of the so-called " $B$. floribunda fortifier". Here, we investigated aspects of the collection this medicinal plant as well as the modes of preparation and dosage used in folk medicine.

\section{Materials and Methods}

Traditional knowledge of herb sellers is acquired through the learning and teaching of older people, usually family members or restricted communities that use plants for disease treatment. Although we use the term "herb sellers", in Brazil they are popularly called "raizeiros" [33] [34], that is, most of these people have little formal education, and have no knowledge about the chemical composition and active principles of plants. Thus, in the following four subsections, an 
ethnopharmacological survey was conducted in the city of Campo Grande, Brazil in order to document the herb sellers' knowledge about the B. floribunda plant. The last sub-sections describe the criteria for quantification and comparing of results with others ones.

\subsection{Research Area}

The study to evaluate traditional knowledge of the herb sellers about the use and preparation of medicinal plant B. floribunda was carried out in Campo Grande, largest city of Mato Grosso do Sul state, Midwest region of Brazil. Figure 1 shows the map of Brazil with the coordinates of Campo Grande city (Latitude: $-20^{\circ} 26^{\prime} 34.01^{\prime \prime}$; L Longitude: $-54^{\circ} 38^{\prime} 47.00^{\prime \prime} \mathrm{W}$ ). It occupies a total surface area of $8,096.051 \mathrm{~km}^{2}$ and an urban area of $154.45 \mathrm{~km}^{2}$ [35]. The estimated population in 2018 in the state is 2,748,023 people. Campo Grande is located near the Brazilian border with Paraguay and Bolivia. It has semi-humid, hot summers, and notably seasonal with a dry winter season from June through September [36]. In addition to local commerce, livestock and family farming are essential practices for the economic sustainability of this city. The City of Campo Grande is divided into 2 districts, called Anhandui and Rochedinho.

Cattle ranching and agriculture has long been the single economic activities of Mato Grosso do Sul. The vegetation around Campo Grande is a tropical savannah called "Cerrado" (a biodiversity tropical savanna with sandy-soil and low-shrub vegetation). The Cerrado is the second largest biome in Brazil and is rich in traditional medicine [37] [38]. In Cerrado, medicinal plants are collected and marketed by herbal sellers and used by indigenous. Studies on medicinal plants from herbal sellers operating in the center of Campo Grande [33] [34], as well as plants used by indigenous people in Mato Grosso do Sul, Brazil, have been conducted in recent years [39]. However, there is no published information on the "fortifying" made from B. Floribunda root in Midwest Brazil.

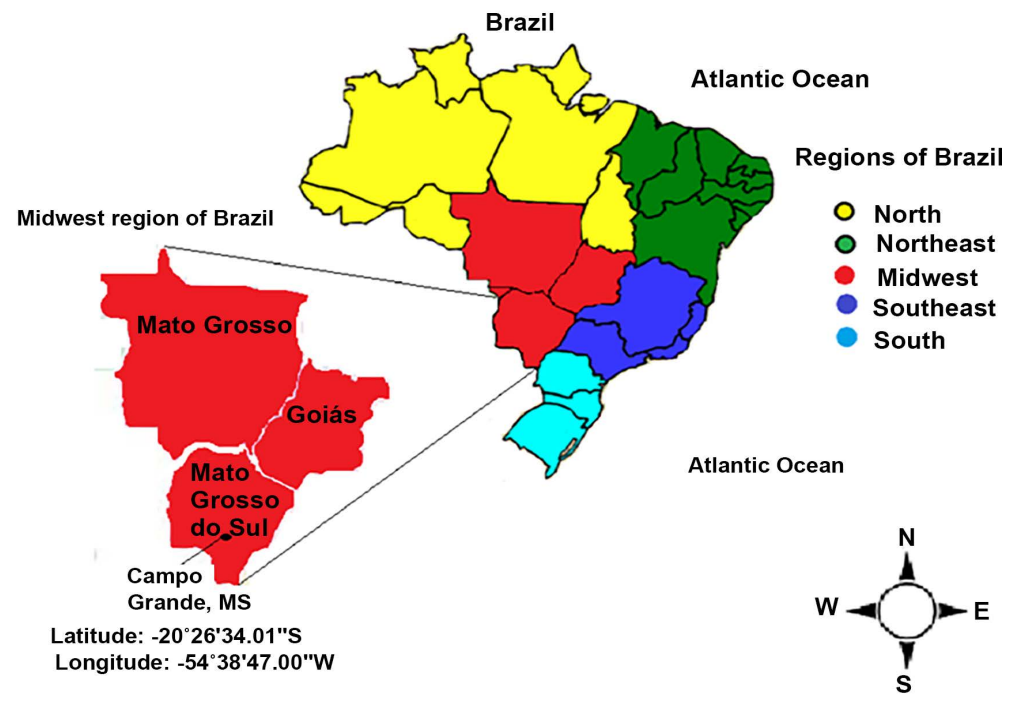

Figure 1. Geographic coordinates of Campo Grande, State of Mato Grosso do Sul, Midwest region of Brazil. 


\subsection{Selection of Herb Sellers and Data Collection}

The present study was conducted following the guidelines of the Code of Brazilian law, this research was registered with the National Genetic Resource Management System and Associated Traditional Knowledge (SisGen, No. A7716EC). Selection of the herb sellers was based on studies published in [33] [34] [39] and preliminary investigation unpublished of the last author, which found that herbal sellers in the city of Campo Grande possess traditional knowledge about the use and availability of $B$. Floribunda.

Only fifteen herb sellers from the City of Campo Grande were approached through recommendations. Subsequently, detailed interviews for purposes of information collection were carried out with the two herb sellers that agreed to participate in the study and have signed an individual written prior informed consent (certificate of access compliance - administrative act by which the responsible agency declares that access to genetic heritage or associated traditional knowledge complied with the requirements of the Law $n^{\circ}$ 13,123, dated May 20, 2015). For data collection, this manuscript was based on the article published in [29]. Thus, data were collected from the following questions: 1) Which B. Floribunda parts are frequently used? 2) Which diseases are commonly treated with the plant? 3) Which place and climate are considered important during harvesting of plants? 4) What are the methods of preparation and routes of administration of the B. floribunda?

\subsection{Bredemeyera Floribunda Wild}

Ethnobotanical information was obtained from a literature search of electronic databases such as Google Scholar, Pubmed and Scopus up to 2019 for publications on B. floribunda used as "tonic or fortifier".

Bredemeyera floribunda Willd (Polygalaceae) is a shrub, reaching up to $2-5$ $\mathrm{m}$, with elliptic leaves, flowers with $6.5-7.5 \mathrm{~mm}$ length, cream color to yellow. This plant grows in Venezuela, Peru, Paraguay and Brazil [40]. This plant has a shrub or lianas shrub with cylindrical, glabrescent, purebulous or villous branches with an indentation of sharp hair. The leaves are simple, alternate, petiolate or subseable. The roots of this plant have almost spongy, bitter and foamy bark when shaken with water [41].

The medicinal use of B. floribunda backs to reports of the botanic George Gardner (1812-1849), who travelled around the country studying the local flora. In the time, B. floribunda roots rasped down and given in cachaça (cane spirit) were used to treat snakebites [42]. In addition to the paper published in [5], we find in the bibliographic review that only Barbosa Rodrigues (1891) cites the species of the genus Bredemeyera as tonic [43].

\subsection{Specimen Collection and Plant Identification}

Plant specimens containing flowers and roots were collected in a rural region indicated by the interviewees. Thus, the collection was performed in June 2016 at a distance of $110 \mathrm{~km}$ from the central region of Campo Grande and near the 
district of Nova Alvorada do Sul (Figure 2 shows a photo of a collected specimen). The specimen was identified by Flávio Macedo Alves; Geraldo Alves Damasceno - Junior and deposited in the herbarium of the Federal University of Mato Grosso do Sul (UFMS)/Brazil under the number CGMS 54366 [28]. Root collection should be performed at approximately a depth of $30-45 \mathrm{~cm}$, as the roots at this depth are soft and undeveloped (Figure 3 ).

\subsection{Sample Preparation by Microwave Digestion}

All solvents and reagents were of the highest commercially available purity grade. The details of the digestion procedure have been published earlier [28]. For microwave digestion, approximately $0.25 \mathrm{~g}$ of roots was directly inserted into a microwave closed vessel plus $1.0 \mathrm{~mL}$ of high purity water $(18 \mathrm{M} \Omega \mathrm{cm}$, Milli-Q, Millipore, Bedford, MA, USA), $2 \mathrm{~mL}$ of $35 \% \mathrm{H}_{2} \mathrm{O}_{2}$ and $3.0 \mathrm{~mL}$ of $\mathrm{HNO}_{3}$ (65\%) solutions were added to each vessel. The heating program was performed in three successive steps as in [28]. Digestions were performed on a focused microwave system (Speedwave four, Berghof, Eningen, BW, Germany). After digestion step, the samples were analyzed by ICP OES.

\subsection{Elemental Analysis by ICP-OES Technique}

Data on the contents of macroelements $(\mathrm{Na}, \mathrm{K}, \mathrm{Ca}, \mathrm{P})$ and microelements $(\mathrm{Fe}$, $\mathrm{Zn}, \mathrm{Ni}, \mathrm{Cu}, \mathrm{Mn}, \mathrm{Co}, \mathrm{Mo}, \mathrm{Cr}, \mathrm{Si}$ ) in $B$. floribunda roots were obtained by ICP-OES (iCAP 6300 Duo, Thermo Fisher Scientific, Bremen, Germany). For calibration, prepare at least five calibration solutions of different concentrations. Data on calibration parameters of ICP OES, Limits of detection (LOD) and limits of quantification (LOQ) were calculated according to previous studies [28].

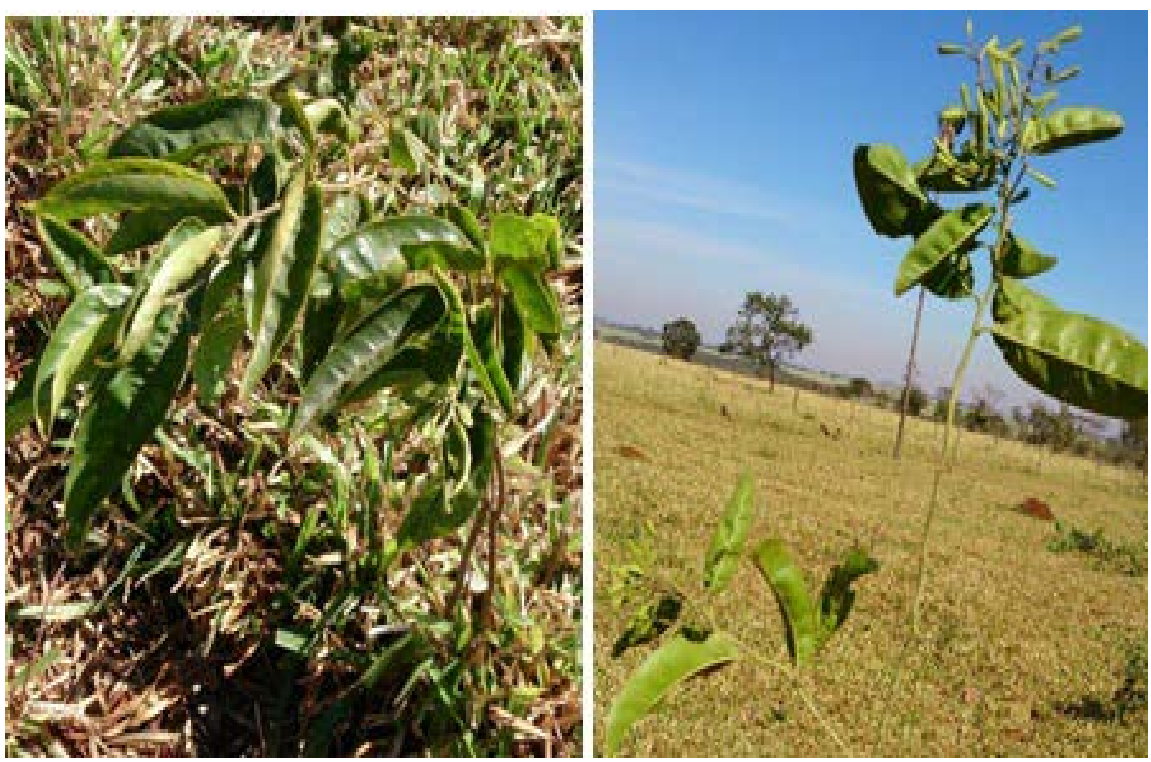

Figure 2. B. Floribunda Wild collected between the city of Campo Grande and the district of Nova Alvorada do Sul, Brazil (Photo: Paula F. S. Tschinkel and Valter A. do Nascimento. 


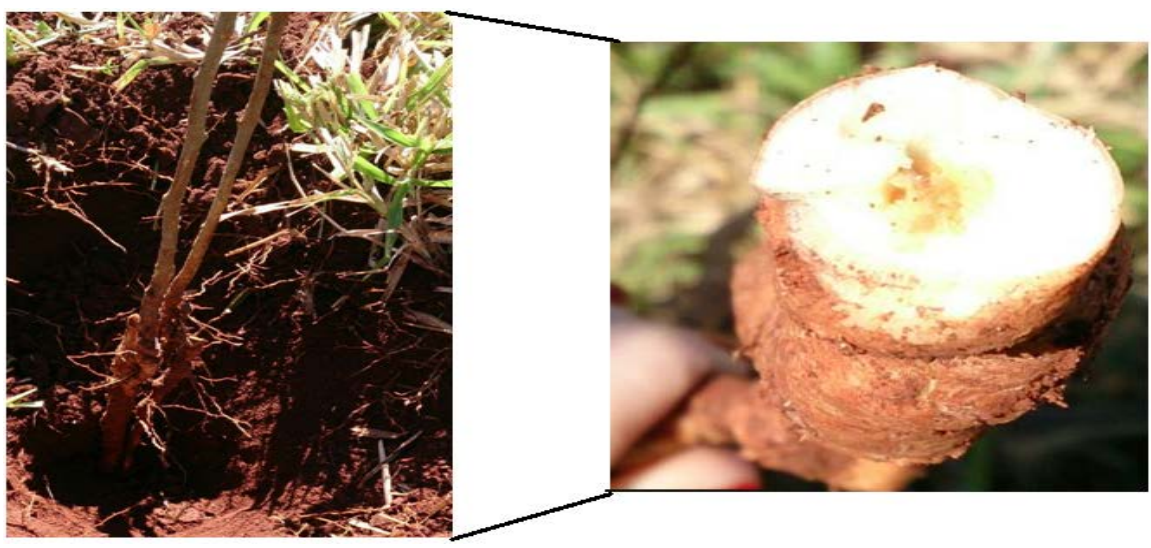

Figure 3. Roots of the B. floribunda medicinal plant taken at the above-mentioned collection site (Photo: Paula F. S. Tschinkel and Valter A. do Nascimento).

\subsection{Comparative Study}

In this paper, the values of microelements and macroelements detected in the roots of $B$. floribunda were compared and evaluate to the limit specification of the DRI values: RDA, AI and UL for adult male (19 - $50 \mathrm{y})$, female $(19-50 \mathrm{y})$ and lactation (19-50 y).

The DRIs are reference that help to guide health professionals in planning and assessing for the nutrient needs of individuals and groups of people, estimating nutrient intakes, without posing health risks, and for other dietary components to promote health and reduce the risk of chronic disease [30]. Nutritional claims based on FDA, which proposes that foods with $10 \%-19 \%$ of the daily value per portion are "good source of" nutrition, while foods that contain $20 \%$ or more of the daily values per portion are considered "excellent sources of" nutrition [44]. However, if a food contains less than $5 \%$ of the percent daily value (DV), it is considered low in that nutrient [44].

In addition, the content value of each element in $B$. floribunda was compared with the values established by WHO and others countries for medicinal plants [45].

\section{Results and Discussion}

\subsection{Data on Selection of Herb Sellers and Data Collection}

Table 1 below shows the data collected about the herbal sellers interviewed. One of the interviewees owns a small farm cultivate their own medicinal plants. It is a local distributor of medicinal herbs to other sellers and homeopathic pharmacies.

Table 2 shows the information arranged according to information on the plant part used in the treatment and type of diseases or food, mode of preparation, common route of administration and dosage. According to the herb sellers, the location of the plant in primary production of crops and livestock should be avoided, it is advisable to look for the plant in Cerrados. Climate is not a factor to consider for root collection. 
Table 1. Data on traditional herbal sellers interviewed.

\begin{tabular}{|c|c|c|}
\hline Categories & Male & Female \\
\hline Religion & Christians & Christians \\
\hline Formal education & high school & secondary education \\
\hline Age & 45 & 40 \\
\hline Years of practice & 20 & 22 \\
\hline $\begin{array}{l}\text { Origin of knowledge } \\
\text { about the use of the } \\
\text { plant } B \text {. floribunda }\end{array}$ & family, indigenous and friends & $\begin{array}{l}\text { Knowledge gained from parents and } \\
\text { grandparents. }\end{array}$ \\
\hline $\begin{array}{l}\text { Where are samples } \\
\text { taken from } B \text {. } \\
\text { floribunda plant? }\end{array}$ & $\begin{array}{l}\text { The plants are collected in } \\
\text { rural areas near the Campo } \\
\text { Grande. }\end{array}$ & $\begin{array}{c}\text { The plants are collected in rural areas near } \\
\text { the Campo Grande. It has a rural property } \\
\text { that cultivates various species of medicinal } \\
\text { plants, including B. Floribunda. }\end{array}$ \\
\hline
\end{tabular}

Table 2. Information on B. Floribunda arranged according to plant part, diseases, plant parts used as food, methods of preparation, route of administration and dosage.

\begin{tabular}{|c|c|c|c|c|c|}
\hline Plant part & Diseases & $\begin{array}{l}\text { Used as } \\
\text { food }\end{array}$ & $\begin{array}{c}\text { Methods } \\
\text { of preparation }\end{array}$ & $\begin{array}{c}\text { Route of } \\
\text { administration }\end{array}$ & Dosage \\
\hline Leaf & No & No & No & No & No \\
\hline Bark/root & $\begin{array}{l}\text { Hypertension } \\
\text { Fatigue } \\
\text { and exhaustion }\end{array}$ & No & $\begin{array}{c}\text { Infusion:30 - } 50 \\
\text { grams plus } 500 \mathrm{ml} \\
\text { water }\end{array}$ & Oral & $\begin{array}{c}\text { There are not } \\
\text { maximum daily dose } \\
\text { per weight or age. }\end{array}$ \\
\hline Root & $\begin{array}{c}\text { Fatigue } \\
\text { and exhaustion }\end{array}$ & Yes & $\begin{array}{c}\text { smooth/creamy } \\
\text { paste: } 15-30 \\
\text { grams plus } 500 \mathrm{ml} \\
\text { water }\end{array}$ & Oral & $\begin{array}{l}\text { There are not } \\
\text { maximum daily dose: } \\
\text { the goal is to eat until } \\
\text { you're satisfied. }\end{array}$ \\
\hline
\end{tabular}

The plant leaves are not used as food or to treat diseases. On the other hand, the bark/roots are used to treat diseases such as hypertension, fatigue and exhaustion; however, these parts of the plant are not used as food. What herbal sellers in folk medicine call "fortifying" is mixing the root or bark of the plant with water. According to herb sellers, the root of the plant can be used to treat hypertension, tiredness and exhaustion. In the infusion process it is recommended to use 30 - 50 grams of root or bark for each $500 \mathrm{ml}$ of boiling water for tea preparation. On the other hand, the roots can be used in food, which is considered as fortifier, the preparation method is performed as follows: an amount of 15 - 30 grams root scraped or crushed, when mixed with $500 \mathrm{ml}$ water, should be well shaken until it becomes a smooth/creamy paste. In our laboratory we made the creamy paste using 7 grams of scraped root plus $120 \mathrm{ml}$ of water (see Figure 4). According to herbal sellers, the root of the plant "fortifying" when used as creamy paste food can be consumed by breastfeeding women, children and adults.

There is no upper limit on daily intake established by age, sex and weight. However, according to animal studies, at higher doses the extract of the dried roots of $B$. floribunda Wild leads to bradycardia and death [7]. 


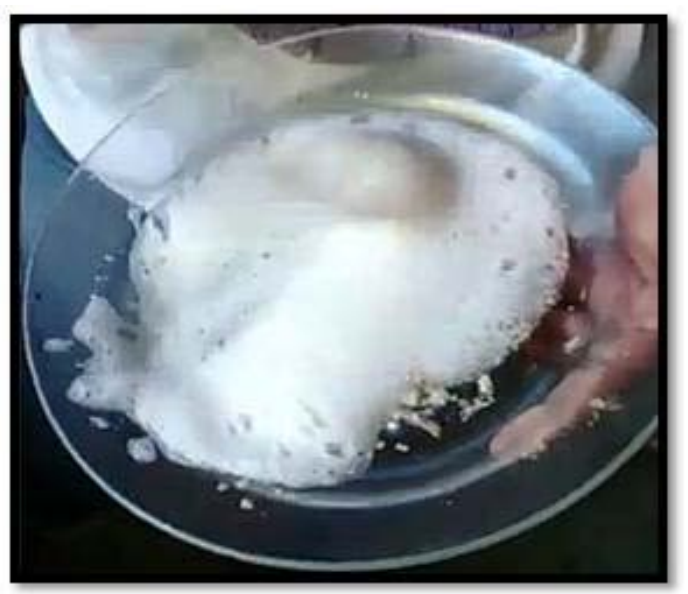

Figure 4. Creamy paste obtained with 7 grams of scraped bark plus $120 \mathrm{ml}$ of water: (Photo: Paula F. S. Tschinkel and Valter A. do Nascimento).

In Figure 4, there are saponification processes of B. floribunda in water. In fact, according to data published in [28] the extract data of the B. floribunda roots presented an emulsifying potential and can be inserted as a natural ingredient in order to make products healthier.

\subsection{Data on Comparative Study}

In Table 3, values of mineral concentrations determined in B. floribunda roots are presented in $\mathrm{mg} / 30 \mathrm{~g}$ of root used in the smooth/creamy paste preparation method (Table 2). In addition, Table 3 shows the daily intake values stipulated by RDA/AI and calculation of the percentage of each element in relation to $\mathrm{RDA} / \mathrm{AI}$, as well as maximum tolerance limit (UL). The concentration of macroelements and microelements in the roots decreases in the order: $\mathrm{Ca}>\mathrm{K}>\mathrm{P}>$ $\mathrm{Na}$ and $\mathrm{Fe}>\mathrm{Mg}>\mathrm{Si}>\mathrm{Mn}>\mathrm{Zn}>\mathrm{Cu}$. The discussion of each element is presented as shown in the sequence of Table 3.

Potassium, K: In Table 3, the content of K observed in roots of the B. floribunda $(16.50 \pm 0.504 \mathrm{mg} / 30 \mathrm{~g})$ correspond to $0.48 \% \pm 0.014 \%$ of the AI for males ( $3400 \mathrm{mg} /$ day), $0.634 \% \pm 0.019 \%$ for females $(2600 \mathrm{mg} /$ day) and $0.589 \% \pm$ $0.018 \%$ of the AI for lactating women [30]. After comparison of the concentration of $\mathrm{K}$ in roots of $B$. Floribunda with those proposed by the AI, it can be concluded that $B$. floribunda has low $\mathrm{K}$ content for males, females and lactating women aged 19 to 50 years old.

The WHO limit for potassium in medicinal plant has not been established yet [45]. In addition, there are yet no established limits for $\mathrm{K}$ tolerable upper intake levels (UL). Until date, there have been no reports of toxicity of potassium from consumption in food. In addition, gastrointestinal symptoms were observed in healthy subjects due to ingestion of potassium in supplements [46]. According to FDA, diets containing foods that are a good source of potassium and that are low in sodium may reduce the risk of high blood pressure [47]. 
Table 3. Macroelements and microelements quantified in the roots of B. floribunda compared to RDA/AI* and UL (mg/day) established for children and adults by FDA for adults, children and pregnancy.

\begin{tabular}{|c|c|c|c|c|c|c|c|c|c|}
\hline $\begin{array}{c}\text { Bredemeyera } \\
\text { floribunda. }^{\mathrm{a}} \\
(\mathrm{mg} / 30 \mathrm{~g})\end{array}$ & $\begin{array}{l}\text { Life stage } \\
\text { Group }\end{array}$ & $\begin{array}{l}{ }^{\mathrm{b}} \mathrm{RDA} / \mathrm{AI}^{*} \\
\text { (mg/day) }\end{array}$ & $\begin{array}{c}\mathrm{UL} \\
\text { (mg/day) }\end{array}$ & $\begin{array}{l}\text { Life stage } \\
\text { Group }\end{array}$ & $\begin{array}{l}{ }^{\mathrm{b}} \mathrm{RDA} / \mathrm{AI}^{*} \\
\text { (mg/day) }\end{array}$ & $\begin{array}{c}\mathrm{UL} \\
\text { (mg/day) }\end{array}$ & $\begin{array}{l}\text { Life stage } \\
\text { Group }\end{array}$ & $\begin{array}{l}{ }^{\mathrm{b}} \mathrm{RDA} / \mathrm{AI}^{*} \\
\text { (mg/day) }\end{array}$ & $\begin{array}{c}\mathrm{UL} \\
\text { (mg/day) }\end{array}$ \\
\hline $\begin{array}{c}\mathrm{K} \\
16.50 \pm 0.504\end{array}$ & $\begin{array}{c}\text { Males } \\
19-50 \mathrm{y}\end{array}$ & $\begin{array}{c}3,400^{*} \\
(0.48 \% \pm 0.014 \%)\end{array}$ & ND & $\begin{array}{l}\text { Famales }^{1} \\
19-50 \mathrm{y}\end{array}$ & $\begin{array}{c}2600^{*} \\
(0.634 \% \pm 0.019 \%)\end{array}$ & ND & $\begin{array}{r}\text { Lactation }^{1} \\
19-50 \mathrm{y}\end{array}$ & $\begin{array}{c}2800^{*} \\
(0.589 \% \pm 0.018 \%)\end{array}$ & ND \\
\hline $\begin{array}{c}\mathrm{Mg} \\
9.55 \pm 0.277\end{array}$ & $\begin{array}{l}\text { Males } \\
19-50 y\end{array}$ & $\begin{array}{c}420 \\
(2.273 \% \pm 0.065 \%)\end{array}$ & 350 & $\begin{array}{l}\text { Females } \\
19-50 y\end{array}$ & $\begin{array}{c}320 \\
(2.984 \% \pm 0.008 \%)\end{array}$ & 350 & $\begin{array}{c}\text { Lactation } \\
19-30 y \\
31-50 y\end{array}$ & $\begin{array}{c}310 \\
320(3.080 \% \pm 0.08 \%)\end{array}$ & 350 \\
\hline $\begin{array}{c}\mathrm{Ca} \\
85.317 \pm 2.76\end{array}$ & $\begin{array}{l}\text { Males } \\
19-50 y\end{array}$ & $\begin{array}{c}1,000 \\
(8.531 \% \pm 0.276 \%)\end{array}$ & 2,500 & $\begin{array}{l}\text { Females } \\
19-50 y\end{array}$ & $\begin{array}{c}1000 \\
(8.531 \% \pm 0.276 \%)\end{array}$ & 2,500 & $\begin{array}{l}\text { Lactation } \\
19-50 \mathrm{y}\end{array}$ & $\begin{array}{c}1000 \\
(8.531 \% \pm 0.276 \%)\end{array}$ & 2,500 \\
\hline $\begin{array}{c}P \\
16.398 \pm 0.345\end{array}$ & $\begin{array}{l}\text { Males } \\
19-50 \mathrm{y}\end{array}$ & $\begin{array}{c}700 \\
(2.34 \% \pm 0.049 \%)\end{array}$ & 4,000 & $\begin{array}{l}\text { Males } \\
19-50 y\end{array}$ & $\begin{array}{c}700 \\
(2.34 \% \pm 0.049 \%)\end{array}$ & 4,000 & $\begin{array}{l}\text { Lactation } \\
19-50 \mathrm{y}\end{array}$ & $\begin{array}{c}700 \\
(2.34 \% \pm 0.049 \%)\end{array}$ & 4,000 \\
\hline $\begin{array}{c}\mathrm{Ni} \\
0.024 \pm 0.006\end{array}$ & $\begin{array}{l}\text { Males } \\
19-50 \mathrm{y}\end{array}$ & ND & 1.0 & $\begin{array}{l}\text { Females } \\
19-50 y\end{array}$ & ND & 1.0 & $\begin{array}{l}\text { Lactation } \\
19-50 \mathrm{y}\end{array}$ & ND & 1.0 \\
\hline $\begin{array}{c}\mathrm{Al} \\
7.149 \pm 0.234\end{array}$ & $\begin{array}{c}\text { Males } \\
19-50 \mathrm{y}\end{array}$ & ND & ND & $\begin{array}{l}\text { Females } \\
19-50 y\end{array}$ & ND & ND & $\begin{array}{l}\text { Lactation } \\
19-50 \mathrm{y}\end{array}$ & ND & ND \\
\hline $\begin{array}{c}\mathrm{Cr} \\
0.081 \pm 0.0012\end{array}$ & $\begin{array}{l}\text { Males } \\
19-50 y\end{array}$ & $\begin{array}{c}0.035^{*} \\
(231.42 \% \pm 3.42 \%)\end{array}$ & ND & $\begin{array}{l}\text { Females } \\
19-50 y\end{array}$ & $\begin{array}{c}0.025^{\star} \\
(324.0 \% \pm 4.80 \%)\end{array}$ & ND & $\begin{array}{c}\text { Lactation } \\
19-50 \mathrm{y}\end{array}$ & $\begin{array}{c}0.045^{\star} \\
(180.0 \% \pm 2.66 \%)\end{array}$ & ND \\
\hline $\begin{array}{c}\mathrm{Cu} \\
0.5637 \pm 0.055\end{array}$ & $\begin{array}{l}\text { Males } \\
19-50 y\end{array}$ & $\begin{array}{c}0.9 \\
(62.63 \pm 6.11)\end{array}$ & 10.0 & $\begin{array}{l}\text { Females } \\
19-50 y\end{array}$ & $\begin{array}{c}0.9 \\
(62.63 \pm 6.11)\end{array}$ & 10.0 & $\begin{array}{l}\text { Lactation } \\
19-50 y\end{array}$ & $\begin{array}{c}1.3 \\
(43.36 \% \pm 4.23 \%)\end{array}$ & 10 \\
\hline $\begin{array}{c}\mathrm{Fe} \\
11.767 \pm 0.285\end{array}$ & $\begin{array}{l}\text { Males } \\
19-50 y\end{array}$ & $\begin{array}{c}8 \\
(145.15 \% \pm 3.56 \%)\end{array}$ & 45 & $\begin{array}{l}\text { Females } \\
19-50 y\end{array}$ & $\begin{array}{c}18 \\
(64.51 \% \pm 1.58 \%)\end{array}$ & 45 & $\begin{array}{l}\text { Lactation } \\
19-50 \mathrm{y}\end{array}$ & $\begin{array}{c}9 \\
(129 \% \pm 3.16 \%)\end{array}$ & 45 \\
\hline $\begin{array}{c}\mathrm{Mn} \\
0.624 \pm 0.015\end{array}$ & $\begin{array}{c}\text { Males } \\
19-50 y\end{array}$ & $\begin{array}{c}2.3^{*} \\
(23.13 \% \pm 0.652 \%)\end{array}$ & 11 & $\begin{array}{l}\text { Females } \\
19-50 y\end{array}$ & $\begin{array}{c}1.8^{*} \\
(34.66 \% \pm 0.833 \%)\end{array}$ & 11 & $\begin{array}{l}\text { Lactation } \\
19-50 \mathrm{y}\end{array}$ & $\begin{array}{c}2.6^{*} \\
(24.0 \% \pm 0.57 \%)\end{array}$ & 11 \\
\hline $\begin{array}{c}\mathrm{Na} \\
5.332 \pm 0.192\end{array}$ & $\begin{array}{c}\text { Male }^{1} \\
19-50 y\end{array}$ & $\begin{array}{c}1,500 \\
(0.355 \% \pm 0.012 \%)\end{array}$ & $2300^{*}$ & $\begin{array}{l}\text { Females } \\
19-50 y\end{array}$ & $\begin{array}{c}1,500 \\
(0.355 \% \pm 0.012 \%)\end{array}$ & $2300^{*}$ & $\begin{array}{l}\text { Lactation }^{1} \\
19-50 \mathrm{y}\end{array}$ & $\begin{array}{c}1,500 \\
(0.355 \% \pm 0.012 \%)\end{array}$ & $2300^{*}$ \\
\hline $\begin{array}{c}\text { Se } \\
13.767 \pm 0.475\end{array}$ & $\begin{array}{c}\text { Males } \\
19-50 y\end{array}$ & $\begin{array}{c}0.055 \\
(25,030.90 \% \pm 863.63 \%)\end{array}$ & 0.4 & $\begin{array}{l}\text { Females } \\
19-50 y\end{array}$ & $\begin{array}{c}0.055 \\
(25030.90 \% \pm 863.6 \%)\end{array}$ & 0.4 & $\begin{array}{l}\text { Lactation } \\
19-50 \mathrm{y}\end{array}$ & $\begin{array}{c}0.070 \\
(>25,030.90 \%)\end{array}$ & 0.4 \\
\hline $\begin{array}{c}\mathrm{Zn} \\
0.249 \pm 0.004\end{array}$ & $\begin{array}{c}\text { Males } \\
19-50 y\end{array}$ & $\begin{array}{c}11 \\
(2.21 \% \pm 0.043 \%)\end{array}$ & 40 & $\begin{array}{l}\text { Females } \\
19-50 y\end{array}$ & $\begin{array}{c}8 \\
(3.048 \% \pm 0.06 \%)\end{array}$ & 40 & $\begin{array}{l}\text { Lactation } \\
19-50 \mathrm{y}\end{array}$ & $\begin{array}{c}12 \\
(2.032 \% \pm 0.04 \%)\end{array}$ & 40 \\
\hline
\end{tabular}

Note: ND = Not determined; ${ }^{a}$ Data published in [28]; ${ }^{\mathrm{b}}$ Recommended Dietary Allowances (RDA) [30], ${ }^{*}$ The value for AI is used when there are no calculated values for the RDA. ${ }^{* *}$ The ULs for magnesium represent intake from a pharmacological agent only and do not include intake from food and water.

Magnesium, Mg: According to data in Table 3, the content of Mg in the root of B. Floribunda was $9.55 \pm 0.277 \mathrm{mg} / 30 \mathrm{~g}$, which correspond to $2.273 \% \pm$ $0.065 \%$ of the RDA for males aged 19 - 50 years ( $420 \mathrm{mg} /$ day), $2.984 \% \pm 0.008 \%$ of RDA for females 19 - 50 years ( $320 \mathrm{mg} /$ day), and $3.080 \% \pm 0.08 \%-2.984 \% \pm$ $0.008 \%$ of the RDA for lactating women $(310-320 \mathrm{mg} /$ day) [30]. From this comparison on the concentration of $\mathrm{Mg}$ in roots of $B$. Floribunda with those proposed by RDA, it can be concluded that B. Floribunda has low Mg content for males, females and lactating women.

The limit set by WHO for Mg in medicinal plant has not been established yet [45]. For all life stage group presented in Table 3, Mg values were lower than UL values for $\mathrm{Mg}$ intake for females, males, children and lactating women (350 $\mathrm{mg} /$ day) [30]. Therefore, the consumption of one portion of roots dos not confers a risk of adverse effects. According to The Office of Dietary Supplements 
(ODS) of the National Institutes of Health (NIH) [48], ingestion of foods with high magnesium concentration does not pose a health risk to healthy individuals because the kidneys eliminate excessive amounts of urine [49].

Calcium, Ca: In Table 3, the concentration of Calcium in roots of B. Floribunda was $85.317 \pm 2.76 \mathrm{mg} / 30 \mathrm{~g}$, which correspond to $8.531 \% \pm 0.276 \%$ of RDA for males, females and lactating women aged 19 - 50 years $(1000 \mathrm{mg} /$ day $)$ [30]. The value of Ca concentration in B. Floribunda roots compared to those proposed by the RDA showed that this plant has Ca concentration required for the nutrition of males, females and lactating women aged 19 to 50 years old.

For medicinal plant the WHO limits not yet been established for Ca. The permissible limit set by UL for male, female and lactation was $2500 \mathrm{mg} /$ day. After comparison, concentration of $\mathrm{Ca}$ in roots of the $B$. floribunda with those proposed by UL, it is found that the plant has Ca low this limit. Daily and long-term ingestion of foods or supplements containing large amounts of calcium can cause health damage. According studies, people who consume high amounts of calcium might have increased risks of prostate cancer and others diseases [50]. Although there is a dilemma in calcium supplementation, this element plays an essential role in health [51].

Phosphorus, P: The phosphorus concentration found in B. floribunda was $16.398 \pm 0.345 \mathrm{mg} / 30 \mathrm{~g}$, which corresponds to $2.342 \% \pm 0.049 \%$ of the RDA (700 $\mathrm{mg} /$ day) for males, females and lactating women aged 19 to 50 years old. Considering the RDA (Table 3 ) for $\mathrm{P}$, the $B$. floribunda has contents low of $\mathrm{P}$ for males, females and lactation. The concentration of $\mathrm{P}$ in the root of $B$. floribunda is lower than the UL limit (4000 mg/day) [30]. Therefore, this concentration of $\mathrm{P}$ in the roots of $B$. Floribunda does not represent a risk of adverse health effects for males, females and lactation. Phosphorus is an essential nutrient for living organisms. It's a key part of ribonucleic acid (RNA) which plays a role in protein synthesis involving mRNA, rRNA and tRNA [52]. However, it is suggested for sick people to adjust their phosphorus intake [53].

Nickel, Ni: There is no established RDA and AI for nickel. In Table 3, the nickel content of $B$. floribunda root $(0.024 \pm 0.0006 \mathrm{mg} / 30 \mathrm{~g})$ is lower than the permitted plant Ni limits (10 $\mathrm{mg} / \mathrm{Kg})$ established by WHO [45], as well as lower than the tolerable upper intake level (1.0 $\mathrm{mg} /$ day) [30].

Food is a major source of exposure for most people. The Environmental Protection Agency (EPA) estimates that an average adult consumes $170 \mu \mathrm{g}$ of nickel per day [54]. After comparison, contents in the B. floribunda root with those proposed by the EPA, it is found that plant accumulate Ni above this limit. It is observed that the $B$. floribunda root has nickel below the value established by UL, but the value of the content above the consumption estimated by EPA. The effects of exposure to any hazardous substance depend on the dose and duration.

Aluminium, Al: The content of $\mathrm{Al}$ in roots of B. Floribunda was $7.149 \pm 0.234$ $\mathrm{mg} / 30 \mathrm{~g}$ (Table 3 ), however, there are no daily intake limits set by the RDA, AI and UL for males, females and lactating women. On the other hand, B. floribunda root content values are close to the oral intake value for humans stipu- 
lated by some countries which range from 2.5 to $13 \mathrm{mg} /$ day [55]. For medicinal plants the WHO limit not yet been established for Al.

The intake of foods with aluminum is low compared with the amount of aluminium consumed when taking aluminum-containing medication [56]. Daily intakes of aluminium were estimated based on the Food and Drug Administration's (FDA) Total Diet Study dietary exposure model. Thus, estimates of aluminium intakes ranged from $8-9$ and $7 \mathrm{mg} /$ day for adult men and women [57]. After comparing, levels of $\mathrm{Al}$ in the roots of B. Floribunda with those proposed by the FDA, it is found this plant accumulates aluminum close to this value. To some extent, exceeding these FDA values over the long term does not mean that there is a serious health hazard. Therefore, the consumption of one portion of root of the $\mathrm{B}$, floribunda does not confer a risk of adverse effects for males, females and lactation woman aged 19 to 50 years old.

Chromium, Cr: The content of Cr observed in root of B. floribunda was 0.081 $\pm 0.0012 \mathrm{mg} / 30 \mathrm{~g}$ (Table 3 ), which correspond to $231.42 \% \pm 3.42 \%$ of the AI for males aged 19 - 59 years $(0.035 \mathrm{mg}$ /day), $324.0 \% \pm 4.80 \%$ of the AI for females aged $19-50$ years $(0.025 \mathrm{mg} /$ day $)$, and $180.0 \% \pm 2.66 \%$ of the AI for lactation aged 19 - 50 years $(0.045 \mathrm{mg} /$ day) [30]. After comparison, concentration of $\mathrm{Cr}$ in roots of $B$. floribunda with those proposed by the AI, it is concluded that roots of this plant are an excellent source off $\mathrm{Cr}$ for males, females and lactation woman aged 19 to 50 years old.

The limit has not yet been established by UL of $\mathrm{Cr}$ for these populations in study. On the other hand, the concentration of $\mathrm{Cr}$ in the B. floribunda is low, when compared with the value established by WHO in medicinal plants (1.3 $\mathrm{mg} /$ day) [45]. According to studies conducted in Greece on the concentration of heavy metals and trace elements in soils, waters and vegetables, such factors do not denote health risk [58].

There is little clinical and scientific evidence that chromium III is toxic to humans due to ingestion of food or supplements. Although there not a higher safe intake level for $\mathrm{Cr}(\mathrm{UL})$, the Food and Nutrition Board acknowledged a potential for adverse effects of high intakes of supplemental trivalent $\mathrm{Cr}$ and advised caution [59].

Cooper, $\mathrm{Cu}$ : The content of Cooper $(\mathrm{Cu})$ in Table 3 was $0.563 \pm 0.005 \mathrm{mg} / 30$ $\mathrm{g}$ for roots of B. floribunda. Thus, the contents of root of B. floribunda correspond to $63.63 \% \pm 6.11 \%$ of $\mathrm{RDA}$ for males and females $(0.9 \mathrm{mg} /$ day $)$, and $43.36 \% \pm 4.23 \%$ for lactating woman (1.3 $\mathrm{mg} /$ day) [30], meaning an excellent source of this element for the life stage group considered in this study.

In Table 3, the content of $\mathrm{Cu}$ in root of the $B$. floribunda is below the values stipulated by UL for this group aged 19 - 50 years $(10 \mathrm{mg} /$ day $)$. Therefore, the consumption of one portion $(30 \mathrm{~g})$ of roots of this plant not represents a risk of adverse health effects.

The WHO limit has not yet been established for $\mathrm{Cu}$ in medicinal plants [45]. However, in countries as China and Singapore, the limit for cooper in medicinal plants at 20 and $150 \mathrm{mg} / \mathrm{Kg}$, respectively [60]. The values obtained in our study 
when presented in units of $\mathrm{mg}$ per $\mathrm{kg}(18.79 \pm 1.86 \mathrm{mg} / \mathrm{Kg})$ are within the values stipulated by these two countries.

Copper is a necessary mineral to energy production and for neurologic and immunologic systems. It's a major contributive in conjuctive tissue maintenance, cooper transportation and metabolism and in antioxidant activity in the organism [61]. Copper deficiency leads to cytopenias, particularly anemia and neutropenia [62] [63].

Iron, Fe: The content of Fe in the analyzed samples was $11.612 \pm 0.285 \mathrm{mg} / 30$ g, which correspond to $145.15 \% \pm 3.56 \%, 64.51 \% \pm 1.58 \%$ and $129.0 \% \pm 3.16 \%$ of $\mathrm{RDA}$ for males $(8 \mathrm{mg} /$ day $)$, females $(18 \mathrm{mg} /$ day) and lactating woman ( 9 $\mathrm{mg} /$ day) [30]. Thus, roots of B. Floribunda with $100 \%$ RDA or more are considered as excellent sources of iron for male, females and lactating women aged 19 to 50 years old.

The maximum tolerable intake level (UL) of iron for men, women and lactation was $45 \mathrm{mg} /$ day [30]. Therefore, the result of Table 3 for Fe is below UL values for the study group. The consumption of one portion of $\mathrm{Fe}$ in root of B. Floribunda does not confer a risk of adverse effects. There are no data on limitation of the concentration iron in medicinal plants established by WHO [45]. On the other hand, in Egypt it ranges between $261 \mathrm{mg} / \mathrm{Kg}$ to $1239 \mathrm{mg} / \mathrm{Kg}$ limit is set for iron in medicinal plants [64]. The value in Table 3 for Fe in units $\mathrm{mg}$ per $\mathrm{Kg}$ $(387.07 \pm 9.50 \mathrm{mg} / \mathrm{Kg})$ are within of the values stipulated by Egypt. However, sufficient data to define a sage lower limit for toxic iron ingestions are not available.

Iron is pivotal for the formation of oxygen-carrying proteins, and for the enzymes involved in energy production. In fact, one of the most important biological functions of iron in living systems is its role in energetic metabolism, due to its capacity to donate and receive electrons [65].

Manganese, Mn: In the roots $B$. Floribunda the concentration of Mn was found to be $0.624 \pm 0.015 \mathrm{mg} / 30 \mathrm{~g}$ (Table 3). These concentrations correspond to $27.13 \% \pm 0.652 \%$ of the AI for male age $19-50$ years $(2.3 \mathrm{mg} /$ day), $34.66 \% \pm$ $0.388 \%$ of the AI for females aged $19-50$ years $(1.8 \mathrm{mg} / \mathrm{day})$, and $24.0 \% \pm$ $0.570 \%$ of the AI for lactation woman (2.6 mg/day) [30]. From this comparison, values of the concentration of the root $B$. Floribunda with those proposed by AI, it is concluded that root B. Floribunda is an excellent source of $\mathrm{Mn}$ for male, females and lactation women aged 19 to 50 years old.

The tolerable upper intake level (UL) at which no risk of adverse health effects to males, female and lactationg women is $11 \mathrm{mg} /$ day. After comparison of the concentration of $\mathrm{Mn}$ in the studied plant with those proposed by UL, it is found that the plant accumulated $\mathrm{Mn}$ below this limit. In addition, for medicinal plants the WHO limits not yet been established for Mn. However, the permissible limit set by Egypt [66] for medicinal plants $(446-338 \mathrm{mg} / \mathrm{Kg})$ is higher than that found in B. Floribunda roots $(20.80 \pm 0.50 \mathrm{mg} / \mathrm{Kg})$.

Manganese is essential to normal immune function, blood sugar regulation, cell energy, reproduction, digestion and carbohydrate metabolism, bone growth 
and helps in defense mechanisms against free radicals [67].

Sodium, Na: The content of Na observed in root of B. floribunda was $5.332 \pm$ $0.192 \mathrm{mg} / 30 \mathrm{~g}$ (Table 3), which correspond to $0.355 \% \pm 0.012 \%$ of the AI for males, female and lactating women aged 19 - 59 years (1500 mg/day) [30]. After comparison, concentration of $\mathrm{Na}$ roots of $B$. floribunda with those proposed by the $\mathrm{AI}$, it is concluded that roots of this plant have below concentration of $\mathrm{Na}$ for males, females and lactation women aged 19 to 50 years old.

Sodium level in Table $3(5.332 \pm 0.192 \mathrm{mg} / 30 \mathrm{~g})$ was below the UL values for consuming $\mathrm{Na}$ in male, females and lactating women $(2300 \mathrm{mg} /$ day). Therefore, one portion of $30 \mathrm{~g}$ of roots not represents a risk of adverse health effects. There are not permissible limit of $\mathrm{Na}$ in medicinal plant stipulated by WHO. Foods with low sodium concentrations are nutritionally important, as excessive dietary salt intake is a major health risk worldwide [68].

Selenium, Se: High selenium concentration was found in the root of B. floribunda $(13.767 \pm 0.475 \mathrm{mg} / 30 \mathrm{~g})$. The obtained results showed that the selenium concentration found in the root of the plant is above $25,030.90 \% \pm 863.63 \%$ of $\mathrm{RDA}$ for the group of people considered in our study $(0.055 \mathrm{mg} /$ day $)$, and is higher than the UL limit (0.4 mg/day) [30]. There are not limit of selenium concentration in medicinal plant in Brazil and World Health organization (WHO). However, manifestation of toxicity symptoms will occur with high $\mathrm{Cr}$ intakes in supplements. In fact, according studies, Selenium can have toxic effects at high doses [69]. Thus, daily and continuous ingestion of high selenium plants may cause toxicity in humans.

Zinc, $\mathrm{Zn}$ : In Table 3, the content of $\mathrm{Zn}$ in roots of the B. floribunda $(0.2439 \pm$ $0.048 \mathrm{mg} / 30 \mathrm{~g}$ ) correspond to $2.21 \% \pm 0.043 \%$ of the RDA for males (11 $\mathrm{mg} /$ day), $3.048 \% \pm 0.060 \%$ for females $(8 \mathrm{mg} /$ day) and $2.032 \% \pm 0.040 \%$ of the $\mathrm{RDA}$ for lactationg women (12 mg/day). After comparing the concentration of $\mathrm{Zn}$ in roots of $B$. Floribunda with those proposed by the RDA [30], it can be concluded that $B$. Floribunda has low $\mathrm{Zn}$ content for males, females and lactating women. The recommended nutrient intakes for zinc differ depending on whether a mow-, moderate-, or high-bioavailability diet is consumed [70]. Acute zinc toxicity from excessive food ingestion is uncommon.

For medicinal plant the WHO limits not yet been established for $\mathrm{Zn}$. The permissible limit set by UL for male, female and lactationg was $40 \mathrm{mg} /$ day. After comparison, concentration of $\mathrm{Zn}$ in roots of the B. floribunda with those proposed by UL, it is found that the plant has $\mathrm{Zn}$ low this limit.

Zinc is an essential trace metal for human health; its deficiency is associated in various degenerative diseases of the nervous system. Zinc plays important roles as an antioxidant to combat and suppress oxidative stress [71].

\section{Conclusions}

In this article, we document the method of preparation and use of medicinal plant B. Floribunda used by the rural population of Midwest Brazil as food to treat fatigue and exhaustion. We hope that the information from this study will 
contribute to conservation development and the inclusion of herbal medicines in the official health services in Brazil.

For the first time, this study evaluated that a $30 \mathrm{~g}$ equivalent portion of $B$. floribunda scraped root is an excellent source of $\mathrm{Cr}, \mathrm{Cu}, \mathrm{Mn}$ and Se for people 19 to 50 years old. However, the $\mathrm{Cu}$ and $\mathrm{Fe}$ content are above the established limit for medicinal plants stipulated by other countries. $\mathrm{K}, \mathrm{Mg}, \mathrm{P}, \mathrm{Na}$ and $\mathrm{Zn}$ contents in the root of the plant are below 5\% RDA. In addition, this does not mean that the plant has no nutritional function for humans.

The results of evaluation in study indicate that the concentration of $\mathrm{Ni}$ found in the root of the plant is above the permissible limit set by Environmental Protection Agency (EPA) while the concentration of $\mathrm{Al}$ is above the Daily intakes Food and Drug Administration's (FDA). The concentration of Se in root of $B$. Floribunda is above of limit established by $\mathrm{UL}$, and $\mathrm{Cr}$ above the permissible limit stipulated by WHO for medicinal plants.

The study revealed that there are no UL established limits for $\mathrm{K}, \mathrm{Mg}, \mathrm{Ni}, \mathrm{Al}$ and $\mathrm{Cr}$ for male, females and lactation women, and also, there are no values for $\mathrm{K}, \mathrm{Mg}, \mathrm{Ni}, \mathrm{Cu}, \mathrm{Fe}, \mathrm{Al}, \mathrm{Na}$, Se and $\mathrm{Zn}$ stipulated by WHO for medicinal plants.

The mineral composition in medicinal plants has an important role to define dosage of secure uses and maximum health benefits. In this way, the use of $B$. floribunda in this quantity of $30 \mathrm{~g}$ is safe for the consumption for some of the determined elements.

The popular use of $B$. floribunda, to enhance immunity and as a fortifier, to boost energy is supported by the elemental content of the plant, rich in copper, manganese and iron, elements which are linked to cell energy and immune defense.

Although no toxicity could be seen regarding the adult population, B. floribunda use by Brazilian population is far extensive, so, further studies should be performed in order to secure children and pregnant women.

Thus, the comparative data of our studies have relevant information for the use of medicinal plants that can be included in the data on the plant species included in the Renisus (National Relation of Medicinal Plants of Interest to SUS).

\section{Acknowledgements}

This research was partially supported by the Brazilian Research Council (CNPq) (CNPq: Process No 311336/2017-5). This study was financed in part by the Coordenação de Aperfeiçoamento de Pessoal de Nível Superior-Brasil (CAPES)-Finance Code 001.

\section{Conflicts of Interest}

The authors declare no conflicts of interest regarding the publication of this paper.

\section{References}

[1] World Health Organization (2011) The World Medicines Situation. Traditional 
Medicines: Global Situation, Issues and Challenges. WHO, Geneva, 2011.

[2] Street, R.A. and Prinsloo, G. (2013) Commercially Important Medicinal Plants of South Africa: A Review. Journal of Chemistry, 2013, Article ID: 205048. https://doi.org/10.1155/2013/205048

[3] Gurib-Fakim, A. (2006) Medicinal Plants: Traditions of Yesterday and Drugs of Tomorrow. Molecular Aspects of Medicine, 27, 1-93. https://doi.org/10.1016/j.mam.2005.07.008

[4] Forzza, R.C., Baumgratz, J.F., Bicudo, C.E.M., Canhos, D.A.L.C., Anibal, A.C., Marcus, A.N., et al. (2012) New Brazilian Floristic List Highlights Conservation Challenges. Bioscience, 62, 39-45. https://doi.org/10.1525/bio.2012.62.1.8

[5] Grandtner, M.M. and Chevrette, J. (2013) Dictionary of Trees: South America: Nomenclature, Taxonomy and Ecology. Academic Press, London, Volume 2, 72.

[6] Alves, N.T.Q., Ximenes, R.M., Jorge, R.J.B., Silveira, J.A.M., Santos, J.V.A., Rodrigues, F.A.P., Costa, P.H.S., Xavier Jr., F.A.F., Evangelista, J.S.A.M., Havt, A., Soares, V.C.G., Toyama, M.H., Oliveira, A.N.A., Araújo, R.M., Alves, R.S. and Monteiro, H.S.A. (2019) Anti-Ophidian Activity of Bredemeyera Floribunda Willd. (Polygalaceae) Root Extract on the Local Effects Induced by Bothrops jararacussu Venom. Brazilian Journal of Medicine and Biological Research, 52, e7581. https://doi.org/10.1590/1414-431x20187581

[7] Bevevino, L.H., Vieira, F.S.A., Cassola, A.C. and Sanioto, S.M.L. (1994) Effect of Crude Extract of Roots of Bredemeyera Floribunda Willd. I. Effect on Arterial Blood Pressure and Renal Excretion in the Rat. Journal of Ethnopharmacology, 43, 197-201. https://doi.org/10.1016/0378-8741(94)90043-4

[8] Agra, M.F., Silva, K.N., Basílio, I.J.L.D., Freitas, P.F. and Barbosa-Filho, J.M. (2008) Survey of Medicinal Plants Used in the Region Northeast of Brazil. Brazilian Journal of Pharmacognosy, 18, 472-508. https://doi.org/10.1590/S0102-695X2008000300023

[9] Pereira, B.M.R., Daros, M.D.R., Parente, J.P. and Matos, F.J.D.A. (1996) Bredemeyeroside D, a Novel Triterpenoid Saponin from Bredemeyera Floribunda: A Potent Snake Venom Antidote Activity on Mice. Phytotherapy Research, 10, 666-669. https://doi.org/10.1002/(SICI)1099-1573(199612)10:8<666::AID-PTR937>3.0.CO;2$\underline{\mathrm{H}}$

[10] Speer, T., Schunk, S.J. and Zewinger, S. (2018) Potassium: An Ion with Dangerous Airs and Graces. European Heart Journal, 39, 543-1545. https://doi.org/10.1093/eurheartj/ehy159

[11] Schwalfenberg, G.K. and Genuis, S.J. (2017) The Importance of Magnesium in Clinical Healthcare. Scientifica, 2017, Article ID: 4179326. https://doi.org/10.1155/2017/4179326

[12] Abbaspour, N., Hurrell, R. and Kelishadi, R. (2014) Review on Iron and Its Importance for Human Health. Journal of Research in Medical Science, 19, 164-174.

[13] Beto, J.A. (2015) The Role of Calcium in Human Aging. Clinical Nutrition Research, 4, 1-8. https://doi.org/10.7762/cnr.2015.4.1.1

[14] Vorland, C.J., Stremke, E.R., Moorthi, R.N. and Gallant, K.M.H. (2017) Effects of Excessive Dietary Phosphorus Intake on Bone Health. Current Osteoporosis Reports, 15, 473-482. https://doi.org/10.1007/s11914-017-0398-4

[15] Dwyer, J.T., Coates P.M. and Smith, M.J. (2018) Dietary Supplements: Regulatory Challenges and Research Resources. Nutrients, 10, 41. https://doi.org/10.3390/nu10010041

[16] Roohani, N., Hurrell, R., Kelishadi, R. and Schulin, R. (2013) Zinc and Its Impor- 
tance for Human Health: An Integrative Review. Journal of Research in Medical Science, 18, 144-157.

[17] Brigelius-Flohé, R. (2018) Selenium in Human Health and Disease: An Overview. In: Michalke, B., Ed., Selenium. Molecular and Integrative Toxicology, Springer, Cham, 3-26. https://doi.org/10.1007/978-3-319-95390-8_1

[18] USEPA (2000) Supplementary Guidance for Conducting Health Risk Assessment of Chemical Mixtures. Risk Assessment Forum Technical Panel, USEPA, Washington DC.

[19] Sunderman Jr., F.W., Dingle, B., Hopfer, S.M. and Swift, T. (1988) Acute Nickel Toxicity in Electroplating Workers Who Accidentally Ingested a Solution of Nickel Sulfate and Nickel Chloride. American Journal of Industrial Medicine, 14, 257-266. https://doi.org/10.1002/ajim.4700140303

[20] Exley, C. (2016) The Toxicity of Aluminium in Humans. Morphologie, 100, 51-55. https://doi.org/10.1016/j.morpho.2015.12.003

[21] Dghaim, R., Khatib, S.A., Rasool, H. and Khan, M.A. (2015) Determination of Heavy Metals Concentration in Traditional Herbs Commonly Consumed in the United Arab Emirates. Journal of Environmental and Public Health, 2015, Article ID: 973878. https://doi.org/10.1155/2015/973878

[22] Haidu, D., Párkányi D., Moldovan, R.I., Savii, C., Pinzaru, I., Dehelean, C. and Kurunczi, L. (2017) Elemental Characterization of Romanian Crop Medicinal Plants by Neutron Activation Analysis. Journal of Analytical Methods in Chemistry, 2017, Article ID: 9748413. https://doi.org/10.1155/2017/9748413

[23] Artwell, K., France, N. and Florence, K. (2017) Investigation of Some Metals in Leaves and Leaf Extracts of Lippiajavanica: Its Daily Intake. Journal of Environmental and Public Health, 2017, Article ID: 1476328. https://doi.org/10.1155/2017/1476328

[24] Ekhator, O.C., Udowelle, N.A., Igbiri, S., Asomugha, R.N., Igweze, Z.N. and Orisakwe, O.E. (2017) Safety Evaluation of Potential Toxic Metals Exposure from Street Foods Consumed in Mid-West Nigeria. Journal of Environmental and Public Health, 2017, Article ID: 8458057. https://doi.org/10.1155/2017/8458057

[25] Kasozi, K.I., Natabo, P.C., Namubiru, S., Tayebwa, D.S., Tamale, A. and Bamaiyi, P.H. (2018) Food Safety Analysis of Milk and Beef in Southwestern Uganda. Journal of Environmental and Public Health, 2018, Article ID: 1627180. https://doi.org/10.1155/2018/1627180

[26] Rocha, L.S., Arakaki, D.G., Bogo, D., Melo, E.S.P., Lima, N.V., de Souza, I., Garrison-Engbrecht, D.A.J., Guimarães, R.C.A. and Nascimento, V.A. (2019) Evaluation of Level of Essential Elements and Toxic Metal in the Medicinal Plant Hymenaea martiana Hayne (Jatobá) Used by Mid-West Population of Brazil. The Scientific World Journal, 2019, Article ID: 4806068. https://doi.org/10.1155/2019/4806068

[27] Zhang, J., Wang, H.-M., Zhao, Y.-L., Zuo, Z.-T., Wang, Y.-Z. and Jin, H. (2015) Comparison of Mineral Element Content in a Functional Food Maca (Lepidium meyenii Walp.) from Asia and South America. Journal of Analytical Methods in Chemistry, 2015, Article ID: 530541. https://doi.org/10.1155/2015/530541

[28] Tschinkel, P.F.S., Melo, E.S P., Dutra, Z.M., Lima, N.V., Arakaki, D.G., Rosa, R.H., Gonçalves, D.A., Souza, I.D., Guimarães, R.C.A., Bogo, D. and Nascimento, V.A.N. (2019) Data on ICP OES and Emulsion Stability of Bredemeyera Floribunda Root Extract: Medicinal Plant Used by the Brazilian Rural Population to Treat Snakebites. Data in Brief, 24, Article ID: 103940.

https://doi.org/10.1016/j.dib.2019.103940 
[29] Boadu, A.A. and Asase, A. (2017) Documentation of Herbal Medicines Used for the Treatment and Management of Human Diseases by Some Communities in Southern Ghana. Evidence-Based Complementary and Alternative Medicine, 2017, Article ID: 3043061. https://doi.org/10.1155/2017/3043061

[30] United States Department of Agriculture (2010) Dietary Reference Intakes: The Essential Guide to Nutrient Requirements, Washington, US. The National Academies Press, Washington DC.

[31] Mousa, A., Naqash, A. and Lim, S. (2019) Macronutrient and Micronutrient Intake during Pregnancy: An Overview of Recent Evidence. Nutrients, 11, 443. https://doi.org/10.3390/nu11020443

[32] Kominiarek, M.A. and Rajan, P. (2016) Nutrition Recommendations in Pregnancy and Lactation. Medical Clinics of North America, 100, 1199-1215. https://doi.org/10.1016/j.mcna.2016.06.004

[33] Nunes, G.P., da Silva, M.F., Resende, U.M. and de Siqueira, J.M. (2003) Plantas medicinais comercializadas por raizeiros no Centro de Campo Grande, Mato Grosso do Sul. Revista Brasileira de Farmacognosia, 13, 83-92. https://doi.org/10.1590/S0102-695X2003000200004

[34] Oliveira, A.K.M., Oliveira N.A., Resende, U.M. and Martins, P.F.R.B. (2011) Ethnobotany and Traditional Medicine of the Inhabitants of the Pantanal Negro Sub-Region and the Raizeiros of Miranda and Aquidauna, Mato Grosso do Sul, Brazil. Brazilian Journal of Biology, 71, No. 1. https://doi.org/10.1590/S1519-69842011000200007

[35] Souza, A., Oliveira, S.S., Aristone, F., Olaofe, Z., Kodicherla, S.P.K., Arsic, M., Ihaddadene, N. and Razika, I. (2018) Modeling of the Function of Distribution of the Ozone Concentration of Surface to Urban Areas. European Chemical Bulletin, 7, 98-105. https://doi.org/10.17628/ecb.2018.7.98-105

[36] Campo Grande Climate: Average Temperature, Weather by Month, Campo Grande Weather Averages-Climate-Data.org. https://en.climate-data.org/south-america/brazil/mato-grosso-do-sul/campo-grand e-3912/

[37] Lima, N.V., Arakaki, D.G., Tschinkel, P.F.S., Silva, A.F., Guimarães, R.A., Hiane, P.A. and Nascimento, V.A. (2017) Investigation of Campomanesia Components: A Fruit of Brazilian Cerrado. In: El-Shemy, H.A., Ed., Active Ingredients from Aromatic and Medicinal Plants, IntechOpen, London, 71-85.

[38] Pott, A., Oliveira, A.K.M., Damasceno-Junior, G.A. and Silva, J.S.V. (2011) Plant Diversity of the Pantanal Wetland. Brazilian Journal of Biology, 71, 265-273. https://doi.org/10.1590/S1519-69842011000200005

[39] Bueno, N.R., Castilho, R.O., Costa, R.B., Pott, A., Pott, V.J., Scheidt, G.N. and Batista, M.S. (2005) Medicinal Plants Used by the Kaiowá and Guarani Indigenous Populations in the Caarapó Reserve, Mato Grosso do Sul, Brazil. Acta Botanica Brasilica, 19, 39-44. https://doi.org/10.1590/S0102-33062005000100005

[40] Lüdtke, R., Souza-Chies, T.T. and Miotto, S.T.S. (2008) Bredemeyera Willd. e Securidaca L. (Polygalaceae) na Região Sul do Brasil. Revista Brasileira de Plantas Medicinais, 6, 69-79.

http://www.ufrgs.br/seerbio/ojs/index.php/rbb/article/view/927

[41] Matos, F.J.A. (2007) Plantas medicinais: Guia de seleção e emprego de plantas usadas em fitoterapia no Nordeste do Brasil. 3rd Edition, UFC, Fortaleza, Volume 1.

[42] Fagg, C.W., Lughadha, E.N., Milliken, W., Hind, D.N. and Brandão, M.G. (2015) Useful Brazilian Plants Listed in the Manuscripts and Publications of the Scottish 
Medic and Naturalist George Gardner (1812-1849). Journal of Ethnopharmacology, 1, 18-29. https://doi.org/10.1016/j.jep.2014.11.035

[43] Marques, M.C.M. (1980) Revisão das espécies do gênero Brodemyera Willd (Polygalaceae) do Brasil. Rodriguesia, 32, No. 54. https://doi.org/10.1590/2175-78601980325416

[44] US Food \& Drug Administration. Guidance for Industry: A Food Labeling Guide. https://www.fda.gov/regulatory-information/search-fda-guidance-documents/guida nce-industry-food-labeling-guide

[45] World Health Organization (WHO) (1996) Permissible Limits of Heavy Metals in Soil and Plants. Geneva, Switzerland.

[46] Newberry, S.J., Chung, M., Anderson, C.A.M., Chen, C., Fu, Z., Tang, A., Zhao, N., Booth, M., Marks, J., Hollands, S., Motala, A., Larkin, J.K., Shanman, R. and Hempel, S. (2018) Sodium and Potassium Intake: Effects on Chronic Disease Outcomes and Risks. Comparative Effectiveness Review No. 206. (Prepared by the RAND Southern California Evidence-Based Practice Center under Contract No. 290-2015-00010-I.) AHRQ Publication No. 18-EHC009-EF. Agency for Healthcare Research and Quality, Rockville, MD.

[47] U.S. Food and Drug Administration (2016) Food Labeling: Revision of the Nutrition and Supplement Facts Labels. Federal Register, 81, 33894-33895. https://www.govinfo.gov/content/pkg/FR-2016-05-27/pdf/FR-2016-05-27.pdf

[48] Office of Dietary Supplements (ODS) of the National Institutes of Health (NIH): Magnesium Fact Sheet for Health Professionals. https://ods.od.nih.gov/factsheets/Magnesium-HealthProfessional/\#en31

[49] Musso, C.G. (2009) Magnesium Metabolism in Health and Disease. International Urology and Nephrology, 41, 357-362. https://doi.org/10.1007/s11255-009-9548-7

[50] Rahmati, S., Azami, M., Delpisheh, A., Ahmadi, M.R.H. and Sayehmiri, K. (2018) Total Calcium (Dietary and Supplementary) Intake and Prostate Cancer: A Systematic Review and Meta-Analysis. Asian Pacific Journal of Cancer Prevention, 19, 1449-1456.

[51] Li, K., Wang, X.F., Li, D.Y., Chen, Y.C., Zhao, L.J., Liu, X.G., Guo, Y.F., Shen, J., Lin, X., Deng, J., Zhou, R. and Deng, H.W. (2018) The Good, the Bad, and the Ugly of Calcium Supplementation: A Review of Calcium Intake on Human Health. Clinical Interventions in Aging, 13, 2443-2452. https://doi.org/10.2147/CIA.S157523

[52] Raven. J.A. (2013) RNA Function and Phosphorus Use by Photosynthetic Organisms. Frontiers in Plant Science, 4, 536. https://doi.org/10.3389/fpls.2013.00536

[53] González-Parra, E., Gracia-Iguacel, C., Egido, J. and Ortiz, A. (2012) Phosphorus and Nutrition in Chronic Kidney Disease. International Journal of Nephrology, 2012, Article ID: 597605. https://doi.org/10.1155/2012/597605

[54] CAS (2005) ATSDR: Toxicological Profile for Nickel. Public Health Service, U.S. Department of Health and Human Services, Atlanta, GA.

https://www.atsdr.cdc.gov/

[55] WHO (1997) Environmental Health Criteria 184-Aluminium. International Programme on Chemical Safety, World Health Organization, Geneva. http://www.inchem.org/documents/ehc/ehc/ehc194.htm

[56] Lione. A. (1985) Aluminum Toxicology and the Aluminum-Containing Medications. Pharmacology \& Therapy, 29, 255-285. https://doi.org/10.1016/0163-7258(85)90032-4

[57] Pennington, J.A.T. and Schoen, S.A. (1995) Estimates of Dietary Exposure to Aluminium. Food Additives \& Contaminants, 12, 119-128. 
https://doi.org/10.1080/02652039509374286

[58] Noli, F. and Tsamos, P. (2016) Concentration of Heavy Metals and Trace Elements in Soils, Waters and Vegetables and Assessment of Health Risk in the Vicinity of a Lignite-Fired Power Plant. Science of the Total Environment, 563-564, 377-385. https://doi.org/10.1016/j.scitotenv.2016.04.098

[59] Food and Nutrition Board, Institute of Medicine Chromium (2001) Dietary Reference Intakes for Vitamin A, Vitamin K, Boron, Chromium, Copper, Iodine, Iron, Manganese, Molybdenum, Nickel, Silicon, Vanadium, and Zinc. National Academy Press, Washington DC, 197-223.

[60] WHO (2005). Quality Control Methods for Medicinal Plant Materials. Geneva.

[61] Ingle, A., Paralikar, P., Shende S., Gupta I., Biswas, J.K., Martins, L. and Rai, M. (2018) Copper in Medicine: Perspectives and Toxicity. Biomedical Applications of Metals. Springer International Publishing AG, Amsterdam, 95-112. https://doi.org/10.1007/978-3-319-74814-6_4

[62] Cathcart, S.J. and Sofronescu, A.G. (2017) Clinically Distinct Presentations of Copper Deficiency Myeloneuropathy and Cytopenias in a Patient Using Excessive Zinc-Containing Denture Adhesive. Clinical Biochemistry, 50, 733-736. https://doi.org/10.1016/j.clinbiochem.2017.03.005

[63] Matak, P., Zumerle, S., Mastrogiannaki, M., El Balkhi, S., Delga, S., Mathieu, J.R.R., Canonne-Hergaux, F., Poupon, J., Sharp, P.A., Vaulont, S. and Peyssonnaux, C. (2013) Copper Deficiency Leads to Anemia, Duodenal Hypoxia, Upregulation of HIF-2 $\alpha$ and Altered Expression of Iron Absorption Genes in Mice. PLoS ONE, 8, e59538. https://doi.org/10.1371/journal.pone.0059538

[64] Sheded, G.M., Pulford, I.D. and Hamed, I.A. (2006) Presence of Major and Trace Elements in Seven Medicinal Plants Growing in the South-Eastern Desert, Egyptian. Journal of Arid Environments, 66, 210-217. https://doi.org/10.1016/j.jaridenv.2005.10.022

[65] Haas, J.D. and Brownlie, T. (2001) Iron Deficiency and Reduced Work Capacity: A Critical Review of the Research to Determine a Causal Relationship. The Journal of Nutrition. 131, 676S-690S. https://doi.org/10.1093/jn/131.2.676S

[66] Egyptian Code (2005) Using Treated Sewage Water in Agricultural Field. National Centre for Housing and Building Research, Ministry of Housing, Utilities and Urban Communities, Egypt.

[67] Fraga, C.G. (2005) Relevance, Essentiality and Toxicity of Trace Elements in Human Health. Molecular Aspects of Medicine, 26, 235-244.

https://doi.org/10.1016/j.mam.2005.07.013

[68] Campbell, N.R.C., Johnson, J.A. and Campbell, T.S. (2012) Sodium Consumption: An Individual's Choice? International Journal of Hypertension, 2012, Article ID: 860954. https://doi.org/10.1155/2012/860954

[69] MacFarquhar, J.K., Broussard, D.L., Melstrom, P., Hutchinson, R., Wolkin, A., Martin, C., Burk, R.F., Dunn, J.R., Green, A.L., Hammond, R., Schaffner, W. and Jones, T.F. (2010) Acute Selenium Toxicity Associated with a Dietary Supplement. Archives of International Medicine, 170, 256-261. https://doi.org/10.1001/archinternmed.2009.495

[70] Food and Nutrition Board of the Institute of Medicine (2001) Dietary Reference Intakes for Vitamin A, Vitamin K, Boron, Chromium, Copper, Iodine, Iron, Manganese, Molybdenium, Nickel, Silicon, Vanadium, and Zinc, National Academy Press, Washington DC.

[71] Lee, S.R. (2018) Critical Role of Zinc as Either an Antioxidant or a Prooxidant in 
Cellular Systems. Oxidative Medicine and Cellular Longevity, 2018, Article ID: 9156285. https://doi.org/10.1155/2018/9156285 